\title{
The effect of transformational leadership climate on employee engagement during digital transformation in Indonesian banking industry
}

\author{
Shinta Winasis $^{a^{*}}$, Djumarno $^{b}$, Setyo Riyanto ${ }^{c}$ and Eny Ariyanto ${ }^{c}$
}

\author{
CH R O N I C L E \\ Article history: \\ Received: September 20, 2020 \\ Received in revised format: \\ January 15,2021 \\ Accepted: January 16, 2021 \\ Available online: January 16, 2021 \\ Keywords: \\ Transformational Leadership \\ Climate \\ Employee Engagement \\ Digital Transformation
}

${ }^{a}$ Doctoral Program University of Mercu buana, Jakarta, Republic of Indonesia

${ }^{b}$ Associate Professor University of Mercu buana, Jakarta, Republic of Indonesia

${ }^{c}$ Graduate School of Management, Mercu Buana University, Jakarta, Republic of Indonesia

\section{Introduction}

The Industrial Age 4.0 has required companies to adopt the latest technology to maintain their existence and sustainability in the business world. The process of change that followed was a radical change that had to run and change quickly to be relevant to the market appetite. In the banking world, especially in Indonesia, the changes that have occurred are driven by, among others changes in customer preferences in making transactions. Customers are increasingly conducting online banking transactions and reducing manual transactions at conventional branches. This change in preferences is accelerating as the world enters the era of the Covid 19 pandemic. Banking business leaders make adjustments by encouraging the acceleration of the digital transformation process in the form of radical changes, changing the entire operational process, implementing new machines and applications and improving the quality of human resources. Changes and new job demand will affect employees, emotionally (Leyer et al., 2020). Furthermore, it is the responsibility of the company to manage the emotions that arise during change into positive energy, so that it can provide a good impetus in the change process (Winasis et al., 2020).

Companies that are undergoing changes must ensure that the employee engagement level is well maintained, because the level of engagement determines the level of service provided (Anand, 2017; Batra 2017). Employee engagement will also direct the company to a higher level of productivity and profitability, ensuring that the changes that occur give the best results for the company (Sim \& Plewa, 2017). Technological developments, especially in the sphere of social media, encourage changes * Corresponding author.

E-mail address: swinasissoejoso@gmail.com (S. Winasis) 
in employee behavior. Nowadays, an employee can easily access information about job vacancies, and can compare employee facilities between companies, which has resulted in a decrease in engagement levels. Among all the indicators are : an increase in employee turnover, absenteeism and productivity levels. The company must maintain this level of engagement by maintaining various variables that may affect the level of engagement to ensure the success of the digital transformation process

In a critical condition due to radical change, companies need leaders who are oriented towards change, even a fundamental factor determining the success of change (Mikkelsen \& Olsen 2019; Meiyani \& Putra, 2019). The leader has a dual role, namely as a leader and a pioneer / agent of change, and the success of the change process depends on the role, attitude and behavior of the leader (Maryam and Fermin 2018). This paper will discuss the impact of rapid changes due to the company's digital transformation on two aspects of human resources transformational leadership climate and employee engagement. The survey was conducted among staff of a private bank in Jakarta who have undergone a digital transformation process for 2 years, and experienced an accelerated transformation due to the Covid 19 Pandemic. The survey results stated in this paper can be expanded for further research.

\section{Literature Review}

\subsection{Transformational Leadership Climate}

The transformational leadership climate was earlier studied by Menges et al. (2011). To support organizational change, a climate that is formed with a transformational spirit is needed, which is shown by the behavior of all leaders in the organization. Furthermore, Menges et al. (2011) explain that more leaders show transformational leadership behavior, i.e., leaders pay attention to their followers individually, provide support and respect and will provide emotional attachment, which results in a positive climate and further support the change process. Transformational leadership behavior has a positive relationship with affective behavior at the individual and team level so that it supports harmonious cooperation in organizations (ManasRodriguez, 2020). Other research showed that the more leaders who adopt transformational leadership style, the stronger positive affective climate will be created in the organizational environment (Guerrero et al., 2017). According to Turel and Gaudioso (2018) technology-related changes in the industrial era 4.0 have a controlled effect on stress levels if a worker has a good relationship with his supervisor and gets assurance about training and learning of the system application. In a positive leadership climate, workers feel they have psychological safety and encourage more accurate employee expectations, have stronger confidence in overcoming their problems and reduce ambiguity in their work environment (Bala \& Venkatesh, 2016).

\subsection{Employee Engagement}

Employee Engagement strategy can help organizations gain a competitive advantage. Engaged workers will be happier in work and personal life, thereby encouraging motivation at work. In the service sector, when technology and processes can be duplicated, people are one of the unique factors that are difficult for competitors to imitate and are considered the most valuable asset if managed properly (Anitha, 2014). Employee engagement is proved to be an antecedent of organizational commitment (Men et al., 2020). There are several factors that determine the level of employee engagement, among others, feelings of being valued and involved in the decision-making process, opportunities to express ideas, career path initiative, company attention to employee health and well-being (Bhuvanaiah, 2014), personal relationships and cooperation between employees, clear and measurable company vision \& mission, also appropriate and supportive managerial behavior (Nink \& Robison, 2016). Managerial behavior is also the key to achieving a high level of engagement. Managers on the one hand, must focus on individuals to gain trust and commitment, but on the other hand, they must also focus on the team as a management unit and pour policies into concrete steps and practices so as to generate the highest performance both in productivity and in the level of customer satisfaction. Managers need to show a positive attitude in a work environment, inspiring and supportive (Popli, 2016). In an organization that is undergoing change, employee engagement is needed, because it determines the level of employee support for company policies. Engaged employees show attention to their work and are sometimes absorbed in their work environment. In the context of a change initiative, they will devote the time and tremendous energy in performing the change- related tasks, resulting in increasing organizational performance (Al-Dalahmeh et al., 2018). Employee engagement 3 indicators: vigor, absorption, and dedication (Nikolova et al., 2019) will indicate the level of readiness of employees in implementing change policies (Matthysen \& Harris, 2018). It is important for companies to maintain the level of employee engagement while conducting changes in organization.

\subsection{Relation between transformational leadership climate with employee engagement}

The relationship between transformational leadership climate and employee engagement has not been widely studied and tested empirically. Research focuses more on the effect of transformational leadership on employee engagement. In various studies, transformational leadership has been shown to have a partial and significant positive effect on employee engagement (Bui et al., 2017). In an organization that is undergoing change, leadership style and climate determine the results of change directly, through the formation of workers' attitudes during the change process, and determine the perceptions, commitment, involvement, and engagement of these workers which will greatly determine the success of the overall process (Appelbaum 
et al., 2015). A transformational leadership style is proven to have a positive relationship with work engagement and encourages proactive employee behavior that supports positive communication and innovation initiatives (Schmitt, 2016). Transformational leadership has been shown to positively moderate the relationship between work engagement and openness to change (Jeong et al., 2016). Based on the explanation from various international studies above, the hypothesis in this study is that the Transformational Leadership Climate in the process of Digital Transformation has a significant effect on Employee Engagement.

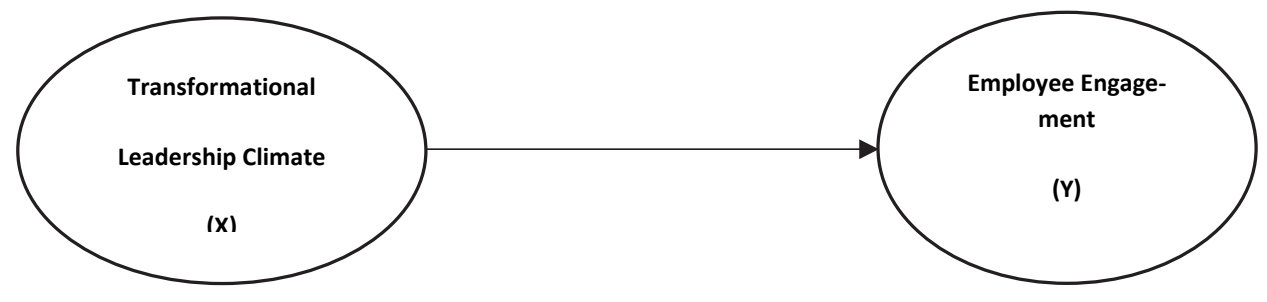

Fig.1. Research Framework

\section{Research Method}

This study uses a quantitative approach and SEM PLS analysis methods with Smart PLS 3 analysis tools.

\subsection{Population dan Sample}

The study was conducted on a population of 6,874 employees of one private banks in Jakarta. The number of samples collected was 448 samples in May 2020, 3 months after Covid-19 was declared officially entering Indonesia and Jakarta was undergoing a lockdown. In this study, the unit of analysis used was employee respondents with a minimum work experience of 2 years

Table 1

Respondent Data

\begin{tabular}{|c|c|c|c|c|c|c|c|c|}
\hline No. & Characteristics & Category & Percentage & No. & Characteristics & Category & \multicolumn{2}{|c|}{ Percentage } \\
\hline \multirow[t]{4}{*}{1} & Respondent Area & South Jakarta & $9.60 \%$ & \multirow[t]{4}{*}{4} & \multirow[t]{4}{*}{ Years in service } & $<5$ & & $18,30 \%$ \\
\hline & & East Jakarta & $10.94 \%$ & & & $5-10$ & & $14.96 \%$ \\
\hline & & Central Jakarta & $27.46 \%$ & & & $10-20$ & & $37,72 \%$ \\
\hline & & West Jakarta & $52.01 \%$ & & & $>20$ Year & & $29,02 \%$ \\
\hline \multirow[t]{2}{*}{2} & Branch Type & Branch & $61.83 \%$ & \multirow[t]{2}{*}{5} & \multirow[t]{2}{*}{ Gender } & Male & & $31,70 \%$ \\
\hline & & Sub Branch & $38.17 \%$ & & & Female & & $68,30 \%$ \\
\hline \multirow[t]{4}{*}{3} & Age & $<20$ & $4.91 \%$ & & & $36-40$ & $13.17 \%$ & \\
\hline & & $21-25$ & $10.71 \%$ & & & $41-45$ & $28.57 \%$ & \\
\hline & & $26-30$ & $9.60 \%$ & & & $46-50$ & $13.17 \%$ & \\
\hline & & $31-35$ & $6.92 \%$ & & & $>50$ & $12.95 \%$ & \\
\hline
\end{tabular}

\subsection{Outer \& Inner Model Analysis}

All indicator and dimension for the research are shown below :

Table 2

Indicators \& Dimensions for Transformational Leadership Style

\begin{tabular}{|c|c|c|}
\hline Dimension & Indicators & Code \\
\hline \multirow{5}{*}{ Idealized Influence } & Leaders set good example for their followers & LC1 \\
\hline & Leaders always speaks optimistic about company future & $\mathrm{LC} 2$ \\
\hline & Proud to have them as my leaders & LC3 \\
\hline & Leaders always do respectful action & LC4 \\
\hline & Leaders have an aura of strength and confidence & LC5 \\
\hline \multirow{3}{*}{ Inspirational Motivation } & Leaders always give enthusiasm to his subordinates & LC6 \\
\hline & Leaders always give motivation to his subordinates & LC7 \\
\hline & Leaders gave me credit and appreciation for my effort & LC8 \\
\hline \multirow{5}{*}{ Intellectual Stimulation } & Leaders always encourages his subordinates to provide the latest ideas & LC9 \\
\hline & Leaders always encourage subordinate to innovate & LC10 \\
\hline & Leaders always suggest new ways to get things done & LC11 \\
\hline & Leaders always care of team engagement & $\mathrm{LC} 12$ \\
\hline & Leaders always encourage teamwork to find solution & LC13 \\
\hline \multirow{3}{*}{ Individual Consideration } & Leaders give personal attention to their subordinates & LC14 \\
\hline & Leaders encourage me to work and try to do better & LC15 \\
\hline & Leaders always took time to listen to my complaints & LC16 \\
\hline \multirow{2}{*}{ Climate } & All leaders of work units \& other related work units show transformational leadership style & LC17 \\
\hline & All leaders of work units \& other related work units are always positive in encouraging the change process & LC18 \\
\hline
\end{tabular}


Table 3

Indicators \& Dimensions for Employee Engagement

\begin{tabular}{|c|c|c|}
\hline Dimension & Indicators & Code \\
\hline \multirow{5}{*}{ Vigor } & I always eager to go to work everyday & EE1 \\
\hline & I always feel passionate about completing assignments & EE2 \\
\hline & I feel strong \& energized while doing tasks & EE3 \\
\hline & I always follow every company event $\&$ activity without being ordered & EE4 \\
\hline & I always actively provide input at every meeting & EE5 \\
\hline \multirow{5}{*}{ Dedication } & I always give the best effort when doing my work & EE6 \\
\hline & I always feel inspired by my occupation & EE7 \\
\hline & I feel proud being part of this organization & EE8 \\
\hline & I always deliver good news about this organization & EE9 \\
\hline & I feel my work id meaningful & EE10 \\
\hline \multirow{4}{*}{ Absorption } & I always concentrate when doing my job & EE11 \\
\hline & I often forget the time when doing my job & EE12 \\
\hline & I am not easy to give up if encounter difficulties at work & EE13 \\
\hline & I feel hard to get away from my job despite the difficulties & EE14 \\
\hline
\end{tabular}

In the Outer Model Test, all indicators but EE6 passed the discriminant validity, composite reliability, Average Variance Extracted (AVE), and Cronbach Alpha tests. The PLS Algorithm model is presented in the image below.

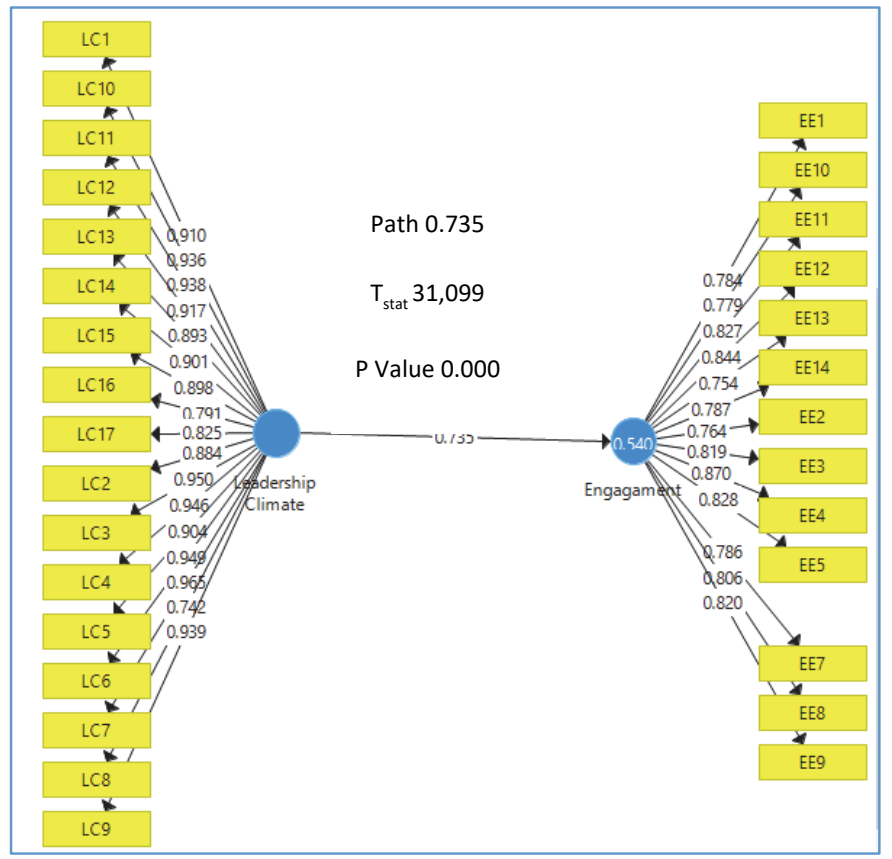

Fig. 2. PLS Algorithm Model

Table 4

Cronbach Alpha, Composite Reliability, AVE

\begin{tabular}{lccc} 
& Cronbach's Alpha & Composite Reliability & Average Variance Extracted (AVE) \\
\hline Engagement & 0.955 & 0.960 & 0.650 \\
Leadership Climate & 0.985 & 0.987 & 0.812 \\
\hline
\end{tabular}

Convergent validity for each variable in this study has a value above 0.7 and the results of the discriminant validity analysis, the overall value of the indicator factor loading on the latent variable shows a value greater than the value of the cross loading. From the results of the above analysis, the composite reliability value for the leadership climate variable was 0.987 , while for the employee engagement variable 0.960 with Cronbach's Alpha 0.985 for the leadership climate variable and 0.955 for the employee engagement variable. The results show excellent consistency for each indicator in measuring its latent variables.

Table 5

$\mathrm{R}^{2}$ Value

\begin{tabular}{lcc} 
& R Square & R Square Adjusted \\
\hline Engagement & 0.540 & 0.539 \\
\hline
\end{tabular}


The results of the inner analysis of the research model showed that the R-square value of the climate leadership variable on employee engagement was $54.0 \%$.

Table 6

$\underline{\mathrm{Q}^{2} \text { Value }}$

\begin{tabular}{lccc}
\hline & SSO & SSE & Q $^{2}$ (=1-SSE/SSO) \\
\hline Engagement & 5824.000 & 3975.926 & 0.317 \\
\hline
\end{tabular}

The results of the variable Leadership climate Stone Geiser Value (Q2) on employee engagement are obtained from the results of blindfolding where the value of Q2 $>0.0$ so that it can be concluded that the leadership climate variable has good relevance in predicting employee engagement variables.

Table 7

$\underline{\text { Path Coefficient \& } \mathrm{T}_{\text {Statistic }}}$

\begin{tabular}{lcccc}
\hline & Original Sample (O) & Standard Deviation (STDEV) & Tstatistics & P Values \\
\hline Leadership Climate $\rightarrow$ Engagement & 0.735 & 0.024 & 31.099 & $\mathbf{0 . 0 0 0}$ \\
\hline
\end{tabular}

The result of the path coefficient of the relationship between leadership climate and employee engagement is 0.735 where this value indicates a positive relationship between leadership climate and employee engagement

\subsection{Hypothesis Test}

The results of the analysis in the research model obtained a statistical $\mathrm{T}_{\text {value }}$ of 31,099 so that the hypothesis is accepted. This illustrates that there is a significant relationship between the transformational leadership climate and employee engagement. With a path coefficient of 0.735 , it means that the influence of the Leadership Climate on employee engagement has a positive value. These results indicate that the positive climate created by the behavior of leaders in a work unit or banking branch determines the level of employee engagement. In organizations, the climate created by leaders that adopt transformational leadership style increases the creativity and analytical skills of employees, especially in conditions of organizational change due to the rapid development of technology (Bushra 2011).

\section{Result and Discussion}

The purpose of this study was to increase awareness and understanding of banking companies regarding the human resources related consequences during radical changes in Industrial 4.0 era. The results of the hypothesis test found that there was a positive and significant relationship between transformational leadership climate and employee engagement, this result is in line with previous research where the climate built with a transformational leadership style has a positive influence on the level of engagement of companies engaged in services (Buil, 2019; Jeong, 2016; Schmitt, 2016). In a company that is undergoing radical change, management must ensure that work unit leaders maintain a positive climate that encourages employee attachment to the company. During the process of change and daily operations, leaders are obliged to maintain a climate of transformational leadership, which is to demonstrate behavior that causes their followers to believe and be amazed, consistently becomes a source of inspiration and motivation, performs intellectual stimulation, gives individual attention, or pays attention to each follower individually and treat them on a personal basis. For further research, it is necessary to consider the influence of other variables that might affect employee engagement during radical changes such as self-efficacy, work stress, organizational culture, and job satisfaction. It is suggested to be discussed further. In addition, it is recommended that surveys be carried out from several types of banks operating in Indonesia, namely government, sharia, regional and private banks, or to be carried out across industries with a larger sample population. The results of this follow-up study are expected to be able to provide meaningful input to the digital transformation process in the Indonesian banking industry and contribute to the success of the industrial transformation process more broadly.

\section{References}

Al-dalahmeh, M., Khalaf, R., \& Obeidat, B. (2018). The effect of employee engagement on organizational performance via the mediating role of job satisfaction: The case of IT employees in Jordanian banking sector. Modern Applied Science, 12(6), 17-43.

Anand, G. (2017). Corporate excellence through governance and employee engagement: A brief analysis. Journal of Commerce and Management Thought, 8(3), 554-562.

Anitha, J, (2014), Determinants of Employee Engagement and their impact on employee performance, International Journal of Productivity and Performance Management 63(3), 308-323 
Appelbaum, S. H., Degbe, M. C., MacDonald, O., \& Nguyen-Quang, T. S. (2015). Organizational outcomes of leadership style and resistance to change (Part One). Industrial and Commercial Training, 47(2), 73-80.

Bala, H., \& Venkatesh, V. (2016) Adaptation to information technology: a Holistic nomological network from implementation to job outcomes. Management Science, 62(1),156-179

Batra, M. M. (2017). Customer experience-an emerging frontier in customer service excellence. In Competition Forum(Vol. 15, No. 1, pp. 198-207). American Society for Competitiveness.

Bhuvanaiah, T. (2014). Employee Engagement : Key to Organizational Success, SCMS Journal of Indian Management, 11(4), 61-71

Bui, H. T., Zeng, Y., \& Higgs, M. (2017). The role of person-job fit in the relationship between transformational leadership and job engagement. Journal of Managerial Psychology, 32(5), 373-386.

Buil, I., Martínez, E., \& Matute, J. (2019). Transformational leadership and employee performance: The role of identification, engagement and proactive personality. International Journal of Hospitality Management, 77(1), 64-75

Bushra, F., Ahmad, U., \& Naveed, A. (2011). Effect of transformational leadership on employees' job satisfaction and organizational commitment in banking sector of Lahore (Pakistan). International journal of Business and Social science, 2(18), 261-267

Guerrero, E. G., Fenwick, K., \& Kong, Y. (2017). Advancing theory development: exploring the leadership-climate relationship as a mechanism of the implementation of cultural competence. Implementation Science, 12(1), 133.

Jeong, S., Hsiao, Y. Song, J. Kim, J., \& Bae, S. (2016). The moderating role of transformational leadership on work engagement: The influences of professionalism and openness to change. Human Resource Development Quarterly, 27(4), 489516

Leyer, M., HirzelL, A. K., \& Moorman, J. (2020). It's mine, I decide what to change: the role of psychological ownership in employees'process Innovation Behaviour. International Journal of Innovation Management, 2150013.

Mañas-Rodríguez, M. A., Enciso-Forero, E., Salvador-Ferrer, C. M., Trigueros, R., \& Aguilar-Parra, J. M. (2020). Empirical Research in Colombian Services Sector: Relation between Transformational Leadership, Climate and Commitment. Sustainability, 12(16), 6659.

Maryam, A. A., \& Fermin Jr, G. C. (2018). Is leader change or challenge? A case study on leadership role. European Journal of Humanities and Social Sciences, 5, 61-66.

Matthysen, M., \& Harris, C. (2018). The relationship between readiness to change and work engagement: A case study in an accounting firm undergoing change. SA Journal of Human Resource Management, 16(1), 1-11.

Men, L. R., Neill, M., \& Yue, C. A. (2020). Examining the Effects of Symmetrical Internal Communication and Employee Engagement on Organizational Change Outcomes. Public Relations Journal, 13(4).

Meiyani, E., \& Putra, A. H. P. K. (2019). The relationship between Islamic leadership on employee engagement distribution in FMCG industry: Anthropology business review. The Journal of Distribution Science, 17(5), 19-28.

Mikkelsen, A., \& Olsen, E. (2019). The influence of change-oriented leadership on work performance and job satisfaction in hospitals-the mediating roles of learning demands and job involvement. Leadership in Health 2019 edition

Menges, J., Water, F., Vogel, B., \& Bruch, H. (2011). Transformational leadership climate: Performance linkages, mechanisms, and boundary conditions at the organizational level. The Leadership Quarterly, 22, 893-909.

Nikolova, I., Schaufeli, W., \& Notelaers, G. (2019). Engaging leader-Engaged employees? A cross-lagged study on employee engagement. European Management Journal, 37(6), 772-783.

Nink, M., \& Robison, J. (2016). The damage inflicted by poor managers. Von Gallup Business Journal: https://news. gallup. com/businessjournal/200108/damage-inflicted-poor-managers. aspx, 244-254.

Popli, S., \& Rizvi, I. A. (2016). Drivers of employee engagement: The role of leadership style. Global Business Review, 17(4), 965-979.

Schmitt, A., Den Hartog, D., \& Belschak, F. (2016). Transformational leadership and proactive work behaviour: A moderated mediation model including work engagement and job strain. Journal of Occupational and Organizational Psychology, 89(3), 588-610

Sim, M., \& Plewa, C. (2017). Customer engagement with a service provider and context: an empirical examination. Journal of Service Theory and Practice, 27(4), 854-876

Turel, O., \& Gaudioso, F. (2018). Techno-stressors, distress and strain: the roles of leadership and competitive climates. Cognition, Technology \& Work, 20(2), 309-324.

Winasis, S., Djumarno, S. R., \& Ariyanto, E. (2020). The impact of the transformational leadership climate on employee job satisfaction during the Covid 19 pandemic in the Indonesian banking industry. PalArch's Journal of Archaeology of Egypt/Egyptology, 17(6), 7732-7742.

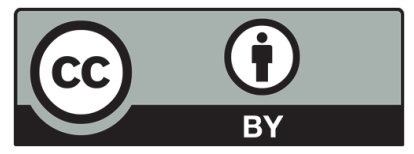

(C) 2021 by the authors; licensee Growing Science, Canada. This is an open access article distributed under the terms and conditions of the Creative Commons Attribution (CC-BY) license (http://creativecommons.org/licenses/by/4.0/). 